\title{
PENGARUH NISBAH BAGI HASIL DEPOSITO MUDHARABAH TERHADAP LOYALITAS NASABAH
}

\section{THE EFFECT OF SHARING RATIO DEFOSIT MUDHARABAH ON CUSTOMER LOYALTY}

\author{
N.S.Sofiah" ${ }^{1}$; R.Trihantana ${ }^{2}$ \\ ${ }_{1}^{1}$ Program Studi Ekonomi Islam Fakultas Ekonomi Islam Universitas Djuanda, Jl. Tol Ciawi \\ No. 1, Kotak Pos 35 Bogor 16720 \\ 2Program Studi Perbankan Syariah Fakultas Ekonomi Islam Universitas Djuanda, Jl. Tol \\ Ciawi No. 1, Kotak Pos 35 Bogor 16720
}

\begin{abstract}
This research aims to determine the effect of revenue sharing mudaraba deposits on customer loyalty. The method of analysis using a quantitative approach, with regression logistic analysis as a tool of analysis. The results showed that from three variables which is consistency, proportional and transparency, the transparency have contributed to developing customer loyalty BMT Blessing Mandiri Sejahtera more higher than the other variables.
\end{abstract}

Keywords: Ratio Profit Sharing, Deposit, Loyalty

\begin{abstract}
ABSTRAK
Penelitian ini bertujuan untuk mengetahui pengaruh nisbah bagi hasil deposito mudharabah terhadap loyalitas nasabah. Metode analisis menggunakan pendekatan kuantitatif, dengan alat analisis regresi logistik. Hasil penelitian menunjukkan dari tiga variabel yaitu konsistensi, proposional dan transparansi yang memiliki kontribusi untuk mengembangkan loyalitas nasabah BMT Berkah Mandiri Sejahtera adalah variabel transparansi.
\end{abstract}

Kata Kunci: Nisbah Bagi Hasil, Deposito, Loyalitas

Sofiah, Neng Siti. 2016. Pengaruh Nisbah Bagi Hasil Deposito Mudharabah Terhadap $\begin{array}{llllll}\text { Loyalitas Nasabah. Jurnal Syarikah } 2 & \text { (2). Hal 235-253. }\end{array}$ 


\section{PENDAHULUAN}

Bank yang berbasis syariah identik dengan sistem nisbah bagi hasil. Istilah nisbah dapat diartikan dengan persentase, bagi hasil yang merupakan return dari kontrak investasi (Karim, 2011: 203). Sistem nisbah bagi hasil dilembaga keuangan syariah salah satunya adalah untuk jenis produk simpanan, yaitu deposito mudharabah atau simpanan berjangka. Produk simpanan berjangka atau deposito mudharabah tidak hanya diterapkan di bank syariah, tetapi juga diterapkan pada lembaga keuangan mikro yang berprinsip syariah seperti koperasi syariah dan BMT.

Simpanan deposito digunakan untuk modal dalam melakukan pengembangan melalui investasi dan pembiayaan usaha. Oleh karena itu, dana deposito harus dijalankan dengan baik dan amanah agar memperoleh pendapatan yang optimal, baik untuk nasabah maupun lembaga itu sendiri. Sistem bagi hasil yang berbasis pada Profit Loss Sharing (PLS) ataupun Revenue Sharing (RS) menyebabkan perolehan keuntungan yang tidak selalu sama atau cenderung berfluktuasi sesuai dengan pendapatan lembaganya. Disamping itu nisbah bagi hasil menjadi bagian yang penting untuk menentukan perolehan keuntungan pada perbankan syariah maupun lembaga keuangan mikro syariah.

Perhitungan dalam menentukan nisbah bagi hasil harus jelas dan transparan, keuntungan yang diperoleh harus sesuai dengan kesepakatan nasabah, karena pendapatan dari keuntungan usaha itulah yang akan didistribusikan kepada nasabah (shahibul maal). Pembagian porsi bagi hasil keuntungan biasanya ditentukan dengan suatu perbandingan dalam persentase, misalnya sebesar 70:30, yang berarti bahwa hasil usaha yang dijalankan oleh mitra usaha akan didistribusikan sebesar sebesar 70 persen kepada pemilik dana (shahibul maal) sebagai deposan dan sebesar 30 persen didistribusikan kepada pengelola dana (mudharib). (Wiyono dan Maulamin, 2013:51).

Tinggi rendahnya nisbah bagi hasil pada lembaga menjadi salah satu faktor penentu kepuasan nasabah terhadap lembaga yang akan menjadi penentu kemajuan usaha BMT. Tingkat kemajuan usaha BMT ditentukan berdasarkan banyaknya nasabah yang mendepositokan hartanya. Jika dibandingkan dengan produk tabungan lainnya, produk deposito lebih flexible untuk diinvestasikan atau disalurkan untuk pembiayaan usaha oleh BMT. Hal ini disebabkan oleh karena jangka waktu penyimpanan dana produk deposito lebih lama dan terukur dan jumlah dana yang didepositokan cenderung jumlahnya lebih besar.

Sementara itu, dari sudut nasabah produk deposito mudharabah ini sangat membutuhkan banyak pertimbangan, terutama pada penentuan tempo/jangka waktu atas kesepakatan awal akad, mengingat dana yang didepositokan dapat diambil hanya pada waktu yang disepakati. Disamping itu lembaga biasanya memiliki kesulitan dalam mempertahankan nasabah, karena loyalitas nasabah dapat didasarkan atas kepuasan nasabah itu sendiri, serta seorang nasabah yang loyal dapat meningkatkan laba melalui pendapatan lembaga dan pendapatan nasabah. Disamping itu apabila pendapatan hasil deposito tinggi, maka nasabah akan cenderung mendepositokan dananya daripada digunakan untuk aktivitas konsumsi. Hal itu disebabkan karena nasabah yang loyalis bukan hanya nasabah 
yang memilih bentuk produk pada lembaga (Soejoto, 2013:3).

\section{MATERI DAN METODE}

Dalam perhitungan bagi hasil harus ada ketetapan agar nasabah dapat memantaunya. Terdapat tiga variabel yang dapat dipertimbangkan dalam melakukan nisbah bagi hasil yaitu proposional, transparansi dan konsistensi. Proporsional adalah pada saat lembaga memberikan nisbah bagi hasil harus sesuai dengan porsinya antara nasabah dan lembaga. Begitu pula dengan perhitungan yang transparansi agar nasabah mendapatkan kepastian atas bagi hasil yang akan diperolehnya. Hal tersebut yang menjadi latar belakang mengapa dalam perhitungan nisbah bagi hasil harus kompetitif dalam produk simpanan deposito yang menggunakan akad mudharabah. Dengan demikian indikator variabel tersebut digunakan untuk mengukur seberapa besar pengaruh dari variabel nisbah hagi hasil terhadap variabel loyalitas nasabah yang hasilnya dapat ditarik kesimpulan tentang ada atau tidaknya pengaruh nisbah bagi hasil terhadap loyalitas nasabah.

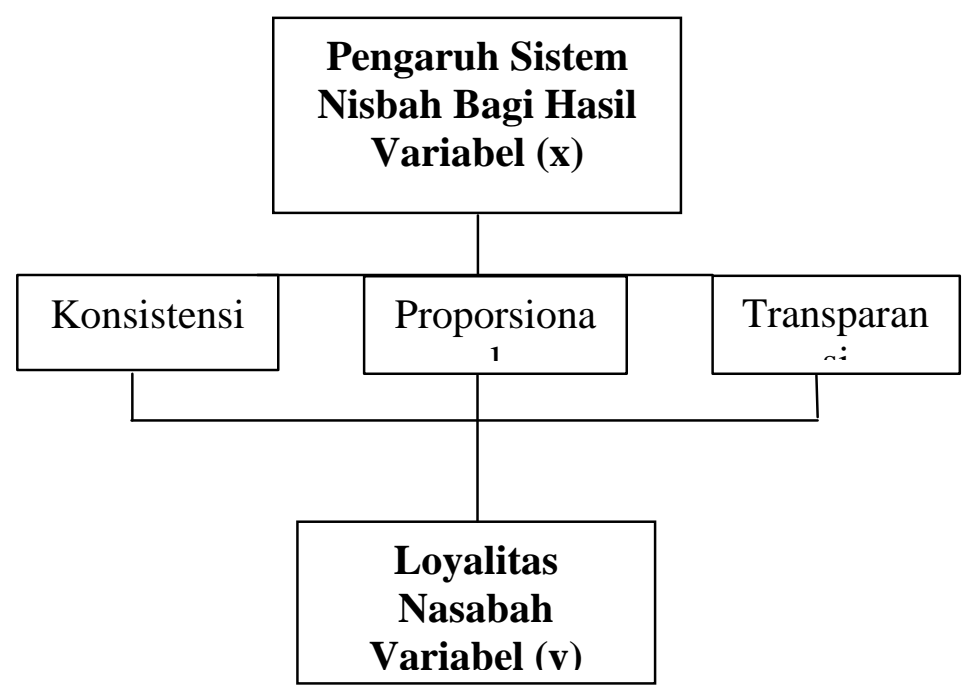

Gambar 1.

Kerangka Pemikiran

\section{Jenis Penelitian}

Jenis penelitian ini merupakan penelitian deskriptif kuantitatif, karena menggambarkan sifat sesuatu yang tengah berlangsung pada saat penelitian dilakukan dan memeriksa sebab-sebab dari suatu gejala tertentu (Sunyoto, 2013:31). Dengan jenis penelitian ini diharapkan dapat menjelaskan fenomena yang ada berdasarkan data dan fakta yang peroleh. Penelitian ini bermaksud untuk memberikan gambaran mengenai pengaruh nisbah bagi hasil deposito mudharabah terhadap loyalitas nasabah.

\section{Populasi dan Sampel}

Populasi adalah jumlah keseluruhan yang terdiri atas obyek atau subyek yang mempunyai karakteristik dan kualitas tertentu yang ditetapkan oleh peneliti untuk diteliti dan kemudian ditarik kesimpulannya (Sujarweni, 2014:65). Populasi dari penelitian ini adalah seluruh nasabah pada BMT Berkah Mandiri Sejahtera.

Sampel adalah bagian dari sejumlah karakteristik yang dimiliki oleh populasi yang digunakan untuk penelitian (Sujarweni, 2014:65). Sampel dalam penelitian ini adalah 30 nasabah deposito mudharabah pada BMT Berkah Mandiri Sejahtera. Sebagaimana dikemukakan oleh Baley dalam Lestari, (2014:66) yang menyatakan bahwa penelitian yang menggunakan analisis dan statistik, ukuran sampel paling minimum adalah 30 .

\section{Teknik Sampling}

Dalam penelitian ini yang menjadi sampel adalah nasabah BMT Berkah Mandiri Sejahtera. Teknik pengambilan sampel menggunakan teknik purposive sampling. Purposive sampling adalah teknik untuk menentukan sampel penelitian dengan pertimbangan tertentu atau kriteria-kriteria tertentu (Sujarweni, 
2014:72). Pada penelitian ini peneliti menggunakan alamat yang dapat dijangkau sebagai pertimbangan untuk mengambil sampel.

\section{Sumber Data}

Sumber data dalam penelitian ini adalah subyek dari mana data diperoleh. Sumber data dalam penelitian ini dikelompokkan menjadi 2 macam, yaitu:

1. Data primer adalah data yang didapat sendiri dari sumber data oleh peneliti langsung pada waktu penelitian dilakukan. Dalam penelitian ini data primer didapatkan melalui kuesioner yang disebarkan kepada nasabah yang menjadi nasabah deposito mudharabah.

2. Data sekunder merupakan data yang diterbitkan atau digunakan oleh organisasi yang bukan pengolahnya (Siregar, 2013:37). Data tersebut terdiri dari dokumen-dokumen, buku, jurnal, internet dan beberapa literatur lainnya yang berkaitan dengan penelitian yang dilakukan.

\section{Teknik Pengumpulan Data}

Pengumpulan data merupakan langkah yang paling utama dalam penelitian. Karena tujuan utama dari penelitian adalah mendapatkan data yang sesuai lingkup penelitian (Sugiyono, 2013:308). Dalam penelitian ini teknik pengumpulan data yang dilakukan adalah sebagai berikut:

a. Kuesioner

Kuesioner merupakan teknik pengumpulan data yang dilakukan dengan cara memberi seperangkat pertanyaan atau pertanyaan tertulis kepada para responden untuk dijawab. Kuesioner yang disebarkan kepada nasabah yang berisikan pertanyaanpertanyaan untuk dijawab dengan pilihan jawaban yang telah disediakan. b. Wawancara

Wawancara adalah salah satu instrumen yang digunakan untuk menggali data secara lisan (Sujarweni, 2014:74-75). Teknik ini dilakukan untuk memperoleh data yang lengkap dan mendalam akan tentang deposito mudharabah yang ada di BMT.

\section{Teknik Analisis Data}

Teknik analisis data yang dilakukan dalam penelitian ini menggunakan beberapa tahapan sebagai berikut:

1. Skala likert adalah skala yang dapat digunakan untuk mengukur sikap, pendapat dan persepsi seseorang atau sekelompok orang tentang fenomena tertentu. Dengan menggunakan skala likert, maka variabel yang akan diukur dijabarkan dari variabel menjadi dimensi, dan dari dimensi diuraikan menjadi indikator setelah itu dari indikator diturunkan menjadi subindikator yang dapat diukur. Akhirnya subindikator dapat dijadikan tolak ukur untuk membantu suatu pertanyaan-pertanyaan yang perlu dijawab oleh responden. Fenomena tertentu telah ditetapkan secara spesifik oleh peneliti, yang selanjutnya disebut sebagai variabel penelitian (Siregar, 2013:37). Dalam penelitian pertanyaan diberikan skor dari 4, 3, 2 dan 1. Berikut adalah tabel pengukuran untuk mengukur ordinal:

Tabel 1.

Perhitungan untuk pengukuran ordinal bagi item pertanyaan

\begin{tabular}{|c|c|}
\hline Nilai & Kriteria \\
\hline 4 & Sangat Setuju \\
3 & Setuju \\
2 & Tidak Setuju \\
1 & Sangat Tidak Setuju \\
\hline
\end{tabular}

Sumber: Teori Issac dan Michael 
Dari pemberian skor yang didapatkan, diperoleh interval antara satu kriteria dengan yang lainnya dengan standar penilaian 1-4 sebagai berikut:

Yang menjadi patokan untuk memperoleh kriteria berdasarkan tanggapan responden adalah:

a) Untuk jawaban sangat setuju pada angka 3,25-4,00

b) Untuk jawaban setuju pada angka 2,49-3,24

c) Untuk jawaban tidak setuju pada angka $1,73-2,48$

d) Untuk jawaban sangat tidak setuju pada angka $0,97-1,72$

2. Uji realibilitas adalah proses pengukuran terhadap ketepatan (konsisten) dari suatu instrumen. Pengujian ini dimaksudkan untuk menjamin instrumen yang digunakan merupakan sebuah instrumen yang handal, konsisten. Stabil dan dependibilitas, sehingga bila digunakan berkali-kali dapat menghasilkan data yang sama.

3. Uji validitas adalah suatu langkah pengujian yang dilakukan terhadap isi (content) dari suatu instrumen dengan tujuan untuk mengukur ketepatan instrumen yang digunakan dalam suatu penelitian (Sujarweni, 2014:79).

4. Regresi logistik dimana analisis ini digunakan untuk mengetahui pengaruh nisbah bagi hasil dalam deposito mudharabah terhadap loyalitas nasabah. Rumus regresi logistik dalam penelitian ini adalah sebagai berikut: (Purnama, 2014:49)

$\mathrm{Y}_{\mathrm{i}}=\alpha+\beta \mathrm{X}_{\mathrm{i}}+\mu_{\mathrm{i}}$

Keteragan:

$\mathrm{Y}_{\mathrm{i}}=$ Peluang Kesetiaan Nasabah BMT

$\mathrm{X}_{\mathrm{i}}=$ Perhitungan Nisbah Bagi Hasil Deposito Mudharabah

$\alpha, \beta=$ Konstanta atau Parameter

$\mu_{\mathrm{i}} \quad=$ Standar Error
Pada dasarnya data penelitian ini bersifat kualitatif yang juga nantinya menggunakan variabel dummy, dimana tahap awalnya adalah merubah data terlebih dahulu kedalam bentuk kuantitatif, misalnya angka 1 adalah laki-laki dan angka 2 adalah perempuan. Lalu membentuk variabel buatan yang mengambil nilai 1 atau 0 , sebagai contoh, 1 menunjukkan bahwa seseorang adalah laki-laki dan 0 menunjukkan perempuan. Dalam penelitian ini terdapat 4 variabel kualitatif yang diubah kedalam variabel dummy, seperti pada tabel berikut:

Tabel 2.

Variabel Dummy Pengaruh Nisbah Bagi Hasil Terhadap Loyalitas Nasabah

\begin{tabular}{|c|c|c|c|}
\hline No. & Variabel & Kategori & Dummy \\
\hline 1. & Konsistensi & $\begin{array}{l}\text { 1= Meyakinkan } \\
\text { 2= Tidak } \\
\text { Meyakinkan }\end{array}$ & $\begin{array}{l}1 \text { = Meyakinkan } \\
0=\text { Tidak } \\
\text { Meyakinkan }\end{array}$ \\
\hline 2. & Proporsional & $\begin{array}{l}1=\text { Sudah Baik } \\
2=\text { Belum Baik }\end{array}$ & $\begin{array}{l}1=\text { Sudah Baik } \\
0=\text { Belum Baik }\end{array}$ \\
\hline 3. & Transparansi & $\begin{array}{l}\text { 1= Dapat } \\
\text { Dipercaya } \\
\text { 2= Tidak Dapat } \\
\text { Dipercaya }\end{array}$ & $\begin{array}{l}1 \text { = Dapat } \\
\text { Dipercaya } \\
0 \text { = Tidak Dapat } \\
\text { Dipercaya }\end{array}$ \\
\hline 4 & Loyalitas & $\begin{array}{l}\text { 1= Loyal } \\
2=\text { Tidak Loyal }\end{array}$ & $\begin{array}{l}1=\text { Loyal } \\
0=\text { Tidak Loyal }\end{array}$ \\
\hline
\end{tabular}

Dalam penelitian ini terdapat dua variabel yang digunakan, yaitu variabel independen dan variabel dependen. Variabel independen dalam penelitian ini dibagi menjadi tiga variabel, diantaranya adalah:

a. Konsistensi

Konsistensi merupakan proses pelaksanaan perjanjian sesuai dengan kesepakatan pada awal akad yang sesuai dengan syarat akad (Wahyuni, 2013:7). Meliputi ketetapan nilai bagi hasil, maka nasabah dapat memantaunya jika suatu saat ada perubahan nisbah bagi hasil yang akan didapatkan setiap akhir bulan. Kategori pada variabel ini terbagi menjadi dua, yaitu: 
1 = Meyakinkan

2 = Tidak Meyakinkan

b. Proporsional

Keuntungan yang dibagihasilkan sesuai dengan proporsional antara shahibul maal (nasabah) dengan mudharib (lembaga), serta proporsinya disepakati pada awal perjanjian. Jika ada pembagian keuntungan sebelum habis masa perjanjian pada kesepakatan awal, maka dianggap sebagai pembagian keuntungan dimuka (Muhammad, 2012:26). Kategori pada variabel ini terbagi menjadi dua, yaitu:

1 = Sudah Baik

2 = Belum Baik

c. Transparansi

Transparansi merupakan salah satu cara agar nasabah mendapat kejelasan dan kepastian secara baik dan ideal dari bagi hasil yang akan diperoleh diakhir bulan. Dalam praktiknya, ketentuan bagi hasil usaha harus ditentukan dimuka pada awal akad/kontrak usaha disepakati oleh pihakpihak yang terlibat dalam akad (Wiyono \& Maulamin, 2013:51). Kategori pada variabel ini terbagi menjadi dua, yaitu:

1 = Dapat Dipercaya

2 = Tidak Dapat Dipercaya

Sementara itu variabel dependen dalam penelitian ini merupakan loyalitas nasabah deposito mudharabah. Definisi loyalitas pelanggan adalah komitmen pelanggan yang bertahan secara mendalam untuk berlangganan kembali atau melakukan pembelian ulang produk/jasa terpilih secara konsisten dimasa yang akan datang, meskipun pengaruh situasi dan usaha-usaha pemasaran mempunyai potensi untuk menyebabkan perubahan perilaku (Oliver, 2005:129). Kategori pada variabel ini terbagi menjadi dua, yaitu:

1 = Loyal

2 = Tidak Loyal

\section{HASIL DAN PEMBAHASAN}

Cikal bakal Koperasi Jasa Keuangan Syariah BMT Berkah Mandiri Sejahtera, awalnya adalah merupakan kantor cabang BMT Ibadurrahman Ciawi Bogor yang operasionalnya sudah dimulai sejak tahun 2006. Namun pada waktu itu untuk pengelolaan manajemen dan laporan keuangannya serta dalam proses pengambilan keputusan terintegrasi pada BMT Ibadurrahman, sehingga untuk memberikan pelayanan yang baik, cepat dan tepat selalu mengalami hambatan.

Dengan kondisi seperti itu, maka pada bulan Januari tahun 2013 seiring dengan adanya permintaan dari anggota dan adanya wacana perubahan Undang-undang Nomor 25 tahun 1992 tentang koperasi, dan Undang-undang ini telah dibatalkan oleh Mahkamah Konstitusi, maka BMT Ibadurrahman Cabang Cisarua dengan resmi dimandirikan menjadi "KJKS BMT BERKAH MANDIRI SEJAHTERA". Yang beralamat di Jln Raya Puncak Cisarua Kabupaten Bogor, dengan surat keputusan Kementrian Negara Koperasi dan Usaha Kecil dan Menengah Republik Indonesia dengan Nomor Badan Hukum: 518/314/KPTS/DISKOPERINDAG/VII/201 3 , yang sesuai dengan kebijakan yang telah diberikan oleh manajemen KBMT Ibadurrahman, maka KJKS Berkah Mandiri Sejahtera mulai tanggal 1 Januari 2013 tetap eksis beroperasi dengan membina anggota sebanyak kurang lebih 1100 anggota yang terdiri dari 700 orang anggota penabung dan 400 orang anggota pembiayaan dengan volume dana yang telah disalurkan untuk pembiayaan pada pengusaha mikro dan kecil sebesar 2,3 Milyar, dengan demikian bahwa KJKS BMT Berkah Mandiri Sejahtera berusaha memfokuskan anggotanya yang berada 
diwilayah Kecamatan Cisarua dan Kecamatan Megamendung, pada sektor jasa keuangan dalam hal menghimpun dana serta menyalurkan kepada anggota, sesuai dengan palsafah "Dari Anggota, Oleh Anggota, Untuk anggota”. Maka bentuk atau jenis idealnya Koperasi Jasa Keuangan Syariah BMT Berkah Mandiri Sejahtera adalah koperasi Simpan Pinjam sesuai dengan surat Keputusan Menteri Koperasi RI No.91/kep/M.KUM/IX/2004. "Tentang Petunjuk Pelaksanaan Kegiatan Usaha Koperasi Jasa Keuangan Syariah".

Koperasi jasa keuangan syariah BMT BERKAH MANDIRI SEJAHTERA memiliki basis kegiatan ekonomi kerakyatan dengan falsafah "Dari Anggota dan Untuk Anggota". Jadi secara prinsip ada perbedaan yang sangat mendasar antara koperasi konvensional (non syariah) dengan koperasi syariah yang terletak pada konsep dan teknis operasional. Koperasi Syariah mengharamkan bunga dengan melihat kaidah halal dan haram dalam melakukan usahanya. Dengan kehadiran KBMT Berkah Mandiri ditengah-tengah masyarakat dilatarbelakangi dengan berbagai hal yang terjadi pada pengusaha mikro dan kecil, diantaranya yaitu:

a) Prosedur teknis bank yang sulit menyentuh lapisan usaha mikro kecil atau pengusaha ekonomi lemah.

b) Kekosongan lembaga ini akhirnya dimanfaatkan oleh pelepas uang atau rentenir yang dirasakan oleh masyarakat sangat mencekik.

c) Keinginan dan antusias masyarakat dalam menjalankan ekonomi Islam sangat tinggi.

d) Pemulihan ekonomi bagi masyarkat berpenghasilan rendah.

e) Pemberdayaan pengusaha golongan ekonomi lemah.

f) Penguatan jaringan usaha kecil. g) Membangun ekonomi kejama'ahan dari, oleh dan untuk ummat.

h) Menghindari sistem ribawi.

\section{Karakteristik BMT Berkah Mandiri Sejahtera}

Pada dasarnya lembaga keuangan mikro memiliki tujuan yang sama yaitu memberikan kesempatan bagi pengusaha kecil yang tidak tersentuh oleh bank untuk mendapatkan fasilitas pembiayaan. Namun BMT Berkah Mandiri Sejahtera lebih menonjolkan karakteristik bisnisnya berdasarkan syariah dengan semangat tolong-menolong (ta'awun) dan saling menguatkan (takaful). Syariah memberikan rambu-rambu bisnis mana yang benar dan yang salah sekaligus menjadi landasan etik di dalam melakukan aktivitas bisnis yang berkeadilan, transaparan dan saling menguntungkan, dengan kata lain syariah bersifat dinamis.

Prinsip gerakan BMT Berkah Mandiri Sejahtera

\section{1) Prinsip Ekonomi}

a. Kekayaan adalah amanah Allah SWT yang tidak dapat dimliki oleh siapapun secara mutlak. Manusia diberikan kebebasan bermuamalah termasuk menjalankan perekonomian selama tidak bertentangan dengan aturan Ilahi.

b. Manusia merupakan khalifah dan pemakmur di muka bumi.

c. Menjunjung keadilan dan menolak praktik riba serta menolak pemusatan sumber daya ekonomi pada segelintiran orang atau sekelompok orang.

\section{2) Prinsip Kebersamaan}

a. Keanggotaan bersifat sukarela

b. Setiap anggota ikut memberikan kontribusi permodalan. 
c. Keputusan ditetapkan secara musyawarah.

d. Pembagian keuntungan didasarkan pada sistem bagi hasil secara proporsional.

e. Mengembangkan sumber daya manusia, sumber daya ekonomi dan sumber daya informasi secara optimal.

f. Menjalin jaringan bisnis antar anggota.

\section{Ruang Lingkup Kegiatan BMT}

BMT Berkah Mandiri Sejahtera dalam kegiatan operasionalnya dibagi menjadi dua divisi, yaitu divisi simpan pinjam (bisnis) dan divisi sosial (non bisnis). Dalam melaksanakan kegiatan bisnis dananya bersumber dari dana pihak ketiga, sedangkan unuk melaksanakan kegiatan sosial dananya bersumber dari zakat, infaq dan shadaqah dikelola oleh Baitul Maal.

a. Divisi Baitul Maal (sosial)

Divisi Baitul Maal bergerak dalam pemulihan ekonomi masyarakat artinya anggota yang mendapat pelayanan dari divisi ini lebih bersifat sosial. Sasaran divisi ini dengan skala prioritas kelompok fakir, miskin yang memiliki kemampuan untuk bersama-sama membuka usaha baru (program penumbuhan wirausaha). Produk pinjamnya adalah qardul hasan atau pinjam kebajikan. Sumber dana kegiatan divisi ini berasal dari dana zakat, infak, sedekah dan hibah.

b. Divisi Baitul Tamwil (Divisi Simpan Pinjam)

Sementara divisi baitul tamwil atau simpan pinjam merupakan divisi yang bergerak dalam pembiayaan pengusaha mikro atau pengusaha ekonomi lemah melalui simpan pinjam tanpa bunga, namun dikemas dengan sistem bagi hasil dana jual beli. Sumber dana yang diperoleh dalam kegiatan divisi ini berasal dari swadaya masyarakat yaitu dari, oleh dan untuk anggota simpatisan BMT. Divisi ini merupakan ciri khas BMT, sebab selain BMT memberikan fasilitas pembiayaan dengan sistem bagi hasil dan jual beli juga melakukan pembinaan manajemen dengan sentuhan nilai-nilai rohani, agar segala bentuk penggunaan dapat transparan baik pada tingkat pengelola maupun anggota.

\section{Karakteristik Responden}

Responden yang dijadikan sampel adalah nasabah BMT Berkah Mandiri Sejahtera yang menjadi nasabah deposito mudharabah mutlaqah dan ditentukan berdasarkan teknik Purposive Sampling, dimana teknik ini merupakan teknik penentuan sampel dengan pertimbangan tertentu. Pada penelitian ini alamat digunakan sebagai pertimbangan untuk mengambil sampel. Untuk karakteristik reponden dikategorikan menjadi jenis kelamin, pendidikan, usia, jenis pekerjaan dan pendapatan.

Berdasarkan hasil penelitian yang dilakukan dari 30 nasabah di BMT Berkah Mandiri Sejahtera yang menjadi nasabah deposito mudharabah dengan menggunakan data yang didapatkan melalui kuesioner yang disebarkan. Jenis kelamin dari 30 nasabah BMT Berkah Mandiri Sejahtera yang menjadi nasabah deposito mudharabah, terdapat 16 orang $(53,33 \%)$ berjenis kelamin laki-laki dan 14 orang $(46,66 \%)$ berjenis kelamin perempuan. Dari hasil tersebut dapat memberikan gambaran mengenai karakteristik nasabah BMT Berkah Mandiri Sejahtera yang menjadi nasabah deposito mudharabah berdasarkan jenis kelaminnya. Jenis kelamin laki-laki mendominasi sebagai nasabah deposito mudharabah di BMT Berkah Mandiri Sejahtera, hal ini disebabkan karena lakilaki yang lebih banyak berwirausaha dan 
mengisi lapangan pekerjaan yang menghasilkan pendapatan. Begitu juga dengan tugasnya sebagai kepala keluarga berkewajiban mencari nafkah bagi keluarganya.

Pendidikan nasabah BMT Berkah Mandiri Sejahtera yang menjadi nasabah deposito mudharabah adalah nasabah yang berpendidikan SD terdapat 7 orang (23,33\%) nasabah berpendidikan SMP 4 orang $(13,33 \%)$ nasabah berpendidikan SMA 12 orang (40\%) nasabah berpendidikan sarjana 7 orang $(23,33 \%)$ dan nasabah yang berpendidikan lainnya adalah 0 orang $(0 \%)$.

Dari data tersebut menunjukkan bahwa nasabah deposito mudharabah pada BMT Berkah Mandiri Sejahtera didominasi oleh mereka yang berpendidikan SMA dengan jumlah 40\%. Hal ini disebabkan lulusan SMA rata-rata masih muda dan masih usia produktif dengan tingkat penghasilan rata-rata menengah keatas. Dan produk deposito mudharabah yang diterapkan pada BMT Berkah Mandiri Sejahtera yaitu jumlah deposito mudharabah minimal Rp. 5.000.000.00-, hal tersebut berpengaruh terhadap karakteristik pendidikan responden pada penelitian ini, dimana pada penelitian ini untuk karakteristik pendidikan responden didominasi oleh mereka yang berpendidikan terakhir SMA.

Usia responden dari 30 nasabah deposito mudharabah BMT Berkah Mandiri Sejahtera terdapat 7 orang (23.33\%) berusia 20 sampai 30 tahun, 17 orang (56.66 \%) berusia 20 sampai 30 tahun, dan 6 orang $(20 \%)$ berusia 20 sampai 30 tahun. Sehingga dari hasil tersebut dapat dilihat bahwa karakteristik nasabah BMT Berkah Mandiri Sejahtera berdasarkan usianya, dimana dalam penelitian ini yang paling dominan adalah usia 36 sampai 45 dengan jumlah presentase $56.66 \%$, hal ini disebabkan karena rata-rata responden yang berusia 36 sampai 45 memiliki jiwa usaha/jiwa bekerja yang produktif dan memiliki pemikiran untuk menyimpan sebagian hartanya untuk masa depan mereka. Sehingga hal tersebut juga mungkin berpengaruh terhadap karakteristik jenis usia responden pada penelitian ini, dimana pada penelitian ini untuk karakteristik usia responden didominasi oleh nasabah yang berusia 36 sampai 45 tahun.

Jenis pekerjaan dari 30 nasabah BMT Berkah Mandiri Sejahtera yang menjadi nasabah deposito mudharabah, terdapat 6 orang (20\%) bekerja sebagai pegawai swasta, 21 orang (70\%) sebagai wirausaha dan lainnya sebanyak 3 orang (10\%), pekerjaan responden yang memilih lainnya antara lain responden yang mempunyai pekerjaan lebih dari satu pekerjaan. Hasil data memperlihatkan bahwa nasabah yang memiliki pekerjaan sebagai wirausaha lebih mendominasi jumlah nasabah deposito mudharabah bahkan lebih dari 50\%. Semua itu disebabkan karena prospek keuntungan seorang wirausaha lebih besar dibandingkan dengan pekerjaan yang lainnya, sehingga seorang nasabah yang memiliki pekerjaan sebagai wirausaha lebih banyak menggunakan deposito mudharabah.

Pendapatan dari 30 nasabah BMT Berkah Mandiri Sejahtera yang menjadi nasabah deposito mudharabah, terdapat sebanyak 13 orang (43.33\%) memiliki pendapatan Rp 5.000.000-Rp 10.000.000,7 orang $(23,33 \%)$ memiliki pendapatan $\mathrm{Rp}$ 15. 000.000-Rp 20.000.000,- 4 orang (13.33\%) memiliki pendapatan $\mathrm{Rp}$ 25.000.000-Rp 30.000.000,- dan 6 orang (20\%) memiliki pendapatan Rp 35.000.000 $\geq$ Rp 50.000.000,--. 
Dari hasil tersebut menggambarkan mengenai karakteristik nasabah BMT Berkah Mandiri Sejahtera yang menjadi nasabah deposito mudharabah berdasarkan pendapatannya. Dimana nasabah BMT Berkah Mandiri Sejahtera merupakan penduduk sekitar. Dan penduduk sekitar BMT tidak banyak yang berpenghasilan besar, nasabah BMT juga tergolong dari mereka yang bekerja sebagai wirausaha namun dengan prospek pendapatan yang tidak terlalu besar atau dibawah Rp 10.000.000. Sedangkan untuk produk deposito mudharabah sendiri simpanan minimalnya adalah Rp 5.000.000 hal tersebut berpengaruh terhadap karakteristik pendapatan responden. Sehingga pada penelitian ini karakteristik pendapatan responden didominasi oleh mereka yang berpendapatan Rp 5.000.000Rp 10.000.000.

\section{Respon Nasabah Terhadap Sistem Nisbah Bagi Hasil BMT Berkah Mandiri Sejahtera.}

Dalam Penelitian ini, respon nasabah terhadap nisbah bagi hasil adalah nasabah sangat setuju dengan sistem bagi hasil sebanyak 19 orang (72.38\%) sedangkan nasabah yang setuju sebanyak 9 orang (25.71\%). Dan yang sangat tidak setuju sebanyak 2 orang (1.90\%). Hasil perhitungan skala likert diperoleh angka kriteria penafsiran sebesar $M=3.5$. Dari hasil ini menunjukkan bahwa rata-rata nasabah "sangat setuju"dengan nisbah bagi hasil.

Penilaian nasabah terhadap perhitungan nisbah bagi hasil menyatakan sangat setuju dengan perhitungan sistem bagi hasil sebanyak 8 orang (33.33\%) sedangkan nasabah yang setuju sebanyak 20 orang $(62.5 \%)$. Dan yang sangat tidak setuju sebanyak 2 orang (4.16\%). Hasil perhitungan skala likert diperoleh angka kriteria penafsiran sebesar $\mathrm{M}=3.2$. Dari hasil ini menunjukkan bahwa rata-rata nasabah "setuju" dengan perhitungan sistem nisbah bagi hasil.

Pandangan responden terhadap nisbah yang terhindar dari sistem maysir (perjudian) terlihat bahwa nasabah sangat setuju dengan perhitungan sistem bagi hasil terhindar dari maysir (perjudian), sebanyak 20 orang (74.07\%) sedangkan nasabah yang setuju sebanyak 9 orang (25\%). Dan yang sangat tidak setuju sebanyak 1 orang (0.92\%). Hasil perhitungan skala likert diperoleh angka kriteria penafsiran sebesar $\mathrm{M}=3.6$. Dari hasil ini menunjukkan bahwa rata-rata nasabah "setuju" dengan perhitungan sistem nisbah bagi hasil terhindar dari maysir (perjudian).

Responden menilai keyakinan perhitungan nisbah bagi hasil adalah sebanyak 21 orang (33.33\%) nasabah sangat setuju dengan keyakinan dalam perhitungan sistem bagi hasil sedangkan nasabah yang setuju sebanyak 5 orang (62.5\%), yang tidak setuju sebanyak 3 orang (4.16\%), dan yang sangat tidak setuju sebanyak 1 orang (0.94\%). Hasil perhitungan skala likert diperoleh angka kriteria penafsiran sebesar $M=3.5$. Dari hasil ini menunjukkan bahwa rata-rata nasabah "setuju" dengan keyakinan dalam perhitungan sistem nisbah bagi hasil.

Sementara itu, penilaian responden terhadap informasi perhitungan nisbah nasabah setuju dengan informasi dalam perhitungan nisbah bagi hasil sebanyak 22 orang $(81.48 \%)$ sedangkan nasabah yang setuju sebanyak 3 orang (13.88\%), yang tidak setuju sebanyak 3 orang (3.70\%), dan yang sangat tidak setuju sebanyak 1 orang $(0.92 \%)$. Hasil perhitungan skala likert diperoleh angka kriteria penafsiran sebesar $\mathrm{M}=$ 3.6. Dari hasil ini menunjukkan bahwa 
rata-rata nasabah "setuju" dengan informasi dalam perhitungan nisbah bagi hasil.

Tanggapan responden terhadap kesepakatan BMT nasabah sangat setuju dengan kesepakatan BMT Berkah Mandiri Sejahtera dengan nasabah sebanyak 23 orang $(83.63 \%)$ sedangkan nasabah yang setuju sebanyak 5 orang (13.63\%), yang tidak setuju sebanyak 1 orang (41.81\%), dan yang sangat tidak setuju sebanyak 1 orang $(0.90 \%)$. Hasil perhitungan skala likert diperoleh angka kriteria penafsiran sebesar $\mathrm{M}=3.6$. Dari hasil ini menunjukkan bahwa rata-rata nasabah "setuju" dengan kesepakatan BMT Berkah Mandiri Sejahtera dengan nasabah.

Penentuan besarnya nisbah bagi nasabah BMT Berkah Mandiri, nasabah sangat setuju dengan penentuan besarnya nisbah sebanyak 17 orang (66.01\%) sedangkan nasabah yang setuju sebanyak 10 orang $(29.12 \%)$, yang tidak setuju sebanyak 2 orang (3.88\%), dan yang sangat tidak setuju sebanyak 1 orang (0.97\%). Hasil perhitungan skala likert diperoleh angka kriteria penafsiran sebesar $\mathrm{M}=3.43$. Dari hasil ini menunjukkan bahwa rata-rata nasabah "setuju" dengan penentuan besarnya nisbah.

1. Responden terhadap perhitungan nisbah menerapkan keadilan

Nasabah sangat setuju dengan perhitungan nisbah menerapkan keadilan 24 orang (83.47\%) sedangkan nasabah yang setuju sebanyak 5 orang (13.04\%), dan yang tidak setuju sebanyak 1 orang (0.90\%). Hasil perhitungan skala likert diperoleh angka kriteria penafsiran sebesar $\mathrm{M}=$ 3.83. Dari hasil ini menunjukkan bahwa rata-rata nasabah "setuju" dengan perhitungan nisbah menerapkan keadilan.

Responden menilai kejelasan dan kepastian dalam perhitungan nisbah pada
BMT Berkah Mandiri mereka menyatakan sangat setuju dengan kejelasan dan kepastian dalam perhitungan nisbah 24 orang (84.95\%) sedangkan nasabah yang setuju sebanyak 5 orang (13.27\%), dan yang tidak setuju sebanyak 1 orang (1,76\%). Hasil perhitungan skala likert diperoleh angka kriteria penafsiran sebesar $\mathrm{M}=$ 3.76. Dari hasil ini menunjukkan bahwa rata-rata nasabah "setuju" dengan kejelasan dan kepastian dalam perhitungan nisbah.

Adapun respons dari responden terhadap sistem bagi hasil menenangkan hati adalah sebagai berikut, nasabah sangat setuju dengan sistem bagi hasil menenangkan hati sebanyak 23 orang (83.63\%) sedangkan nasabah yang setuju sebanyak 5 orang (13.63\%), yang tidak setuju sebanyak 1 orang (1.81\%), dan yang sangat tidak setuju sebanyak 1 orang (0.90\%). Hasil perhitungan skala likert diperoleh angka kriteria penafsiran sebesar $\mathrm{M}=$ 3.6. Dari hasil ini memperlihatkan bahwa rata-rata nasabah "setuju" dengan sistem bagi hasil menenangkan hati.

Responden menanggapi tentang bagi hasil menguntungkan nasabah, responden sangat setuju dengan bagi hasil menguntungkan nasabah sebanyak 22 orang (80\%) sedangkan nasabah yang setuju sebanyak 7 orang (13.09\%), yang dan yang sangat tidak setuju sebanyak 1 orang $(0.90 \%)$. Hasil perhitungan skala likert diperoleh angka kriteria penafsiran sebesar $\mathrm{M}=3$ 3.6. Dari hasil ini menunjukkan bahwa rata-rata nasabah "setuju" dengan bagi hasil menguntungkan nasabah.

Pandangan responden terhadap nisbah bagi hasil sesuai dengan fakta, nasabah sangat setuju dengan mempercayakan dana dikelola oleh BMT sebanyak 20 orang (23.39\%) sedangkan nasabah yang setuju sebanyak 9 orang (24.77\%), dan yang tidak 
setuju sebanyak 1 orang (1.83\%). Hasil perhitungan skala likert diperoleh angka kriteria penafsiran sebesar $\mathrm{M}=3.63$. Dari hasil ini menunjukkan bahwa rata-rata nasabah "setuju" dengan mempercayakan dana dikelola oleh BMT Berkah Mandiri Sejahtera.

Responden menyatakan responnya terhadap transaksi deposito mudharabah mudah dengan hasil nasabah sangat setuju dengan transaksi deposito mudharabah mudah sebanyak 21 orang (76.36\%) sedangkan nasabah yang setuju sebanyak 8 orang (21.81\%), dan yang tidak setuju sebanyak 1 orang (1.81\%). Hasil perhitungan skala likert diperoleh angka kriteria penafsiran sebesar $\mathrm{M}=3.66$. Dari hasil ini menunjukkan bahwa rata-rata nasabah "setuju" dengan transaksi deposito mudharabah mudah.

Pendapat responden terhadap penggunaan deposito mudharabah, nasabah sangat setuju dengan akan selalu menggunakan deposito mudharabah sebanyak 20 orang (76.36\%) sedangkan nasabah yang setuju sebanyak 9 orang (21.81\%), dan yang tidak setuju sebanyak 1 orang (1.81\%). Hasil perhitungan skala likert diperoleh angka kriteria penafsiran sebesar $\mathrm{M}=$ 3.66. Dari hasil ini menunjukkan bahwa rata-rata nasabah "setuju" dengan akan selalu menggunakan deposito mudharabah.

2. Responden terhadap kenyamanan atas pelayanan produk deposito mudharabah

Nasabah sangat setuju dengan kenyamanan dengan pelayanan produk deposito mudharabah sebanyak 18 orang (72\%) sedangkan nasabah yang setuju sebanyak 6 orang (18\%), yang tidak setuju sebanyak 4 orang (8\%), dan yang sangat tidak setuju sebanyak 2 orang (2\%). Hasil perhitungan skala likert diperoleh angka kriteria penafsiran sebesar $M=6.33$. Dari hasil ini menunjukkan bahwa rata-rata nasabah "setuju" dengan kenyamanan dengan pelayanan produk deposito mudharabah.

Pendapat responden terhadap rekomendasi positif deposito mudharabah menyatakan bahwa nasabah sangat setuju dengan rekomendasi positif mengenai deposito mudharabah sebanyak 19 orang (69.72\%), sedangkan nasabah yang setuju sebanyak 11 orang (30.27\%). Hasil perhitungan skala likert diperoleh angka kriteria penafsiran sebesar $\mathrm{M}=3.63$. Dari hasil ini menggambarkan bahwa rata-rata nasabah "setuju" rekomendasi positif mengenai deposito mudharabah.

Tanggapan responden terhadap saran menjadi nasabah BMT dapat dilihat bahwa nasabah sangat setuju dengan menyarankan kepada teman, saudara untuk menjadi nasabah BMT sebanyak 19 orang $(69.72 \%)$, sedangkan nasabah yang setuju sebanyak 11 orang (30.27\%). Hasil perhitungan skala likert diperoleh angka kriteria penafsiran sebesar $M=3.63$. Dari hasil ini menunjukkan bahwa rata-rata nasabah "setuju" dengan menyarankan kepada teman, saudara untuk menjadi nasabah BMT Berkah Mandiri Sejahtera.

Responden menanggapi tentang kebanggaan menjadi nasabah BMT, dimana nasabah sangat setuju dengan merasa bangga menjadi nasabah BMT sebanyak 22 orang $(79.27 \%)$, sedangkan nasabah yang setuju sebanyak 7 orang (18.91\%), dan yang tidak setuju sebanyak 1 orang (1.80\%). Hasil perhitungan skala likert diperoleh angka kriteria penafsiran sebesar $\mathrm{M}=$ 3.7. Dari hasil ini menunjukkan bahwa rata-rata nasabah "setuju" dengan merasa bangga menjadi nasabah BMT.

Tanggapan responden terhadap kesetiaan kepada BMT menyatakan 
nasabah sangat setuju dengan kesetiaan kepada BMT Berkah Mandiri Sejahtera sebanyak 18 orang (87.28\%) sedangkan nasabah yang setuju sebanyak 11 orang (30.84\%), dan yang tidak setuju sebanyak 1 orang (1.86\%). Hasil perhitungan skala likert diperoleh angka kriteria penafsiran sebesar $\mathrm{M}=3.56$. Dari hasil ini menunjukkan bahwa rata-rata nasabah "setuju" dengan kesetiaan kepada BMT Berkah Mandiri Sejahtera.

Penilaian responden terhadap produk lain selain deposito mudharabah, nasabah sangat setuju dengan terhadap produk lain selain deposito mudharabah sebanyak 22 orang $(79.27 \%)$, sedangkan nasabah yang setuju sebanyak 7 orang (18.91\%), dan yang tidak setuju sebanyak 1 orang (1.81\%). Hasil perhitungan skala likert diperoleh angka kriteria penafsiran sebesar $\mathrm{M}=$ 3.7. Dari hasil ini menunjukkan bahwa rata-rata nasabah "setuju" dengan terhadap produklain selain deposito mudharabah.

Responden memandang ketertarikan produk yang ditawarkan BMT dengan penilaian sangat setuju dengan pelayanan produk deposito mudharabah yang memuaskan sebanyak 20 orang (73.39\%) sedangkan nasabah yang setuju sebanyak 9 orang $(24.77 \%)$, dan yang tidak setuju sebanyak 1 orang (1.83\%). Hasil perhitungan skala likert diperoleh angka kriteria penafsiran sebesar $\mathrm{M}=3.63$. Dari hasil ini menunjukkan bahwa rata-rata nasabah "setuju" dengan pelayanan produk deposito mudharabah yang memuaskan.

Adapun penilaian responden terhadap loyalitas dengan BMT, nasabah sangat setuju dengan loyalitas terhadap BMT Berkah Mandiri Sejahtera sebanyak 20 orang (73.39\%) sedangkan nasabah yang setuju sebanyak 9 orang (24.77.\%), dan yang tidak setuju sebanyak 1 orang (1.83\%). Hasil perhitungan skala likert diperoleh angka kriteria penafsiran sebesar $\mathrm{M}=$ 3.6. Dari hasil ini menunjukkan bahwa rata-rata nasabah "setuju" dengan loyalitas terhadap BMT Berkah Mandiri Sejahtera.

\section{Uji Reliabilitas dan Validitas}

Uji realibilitas dari masing-masing faktor menggunakan Cronbachs Alpha. Kuesioner dapat reliabel bila nilai koefisien alpha lebih besar $>0,5$. Hasil dari penelitian ini dapat dilihat dalam tabel berikut:

Tabel 3.

Nilai Statistik Reliabilitas

Cronbach's N of Items

Alpha

.972 25

Dari hasil pengujian maka semua instrumen dikatakan reliabel karena nilai koefisien Cronbach Alpha diperoleh lebih besar dari 0,5 $(\alpha \geq 0,5)$ yaitu sebesar 0,972. Dengan demikian instrumen yang diterapkan pada penelitian ini cukup handal dalam mengukur persepsi responden terhadap variabel yang diteliti dan dapat dilanjutkan ke tahap selanjutnya.

Uji validitas ialah untuk menguji kuisioner layak dan digunakan sebagai intrumen penelitian. Kriteria dari validitas yaitu bila koefisien korelasi masing-masing pernyataan dengan nilai Correected Item Total Correlation lebih tinggi atau sama dengan nilai $r$ tabel. Maka dinyatakan valid (nilai $r$ tabel dengan responden 30 orang adalah 0,361). Dari 25 pertanyaan kuisioner menunjukkan nilai CITC lebih besar dari 0,36 dengan nilai CITC terendah adalah 0,494 pada pertanyaan ketujuh. Ini berarti bahwa semua pernyataan kuisioner valid dan dapat dilanjutkan untuk penelitian dan analisis lebih lanjut. 


\section{Analisis Data}

Dari hasil analisis dengan menggunakan alat analisis regresi logistik memperoleh hasil pengaruh dari setiap variabel nisbah bagi hasil deposito mudharabah terhadap loyalitas nasabah. Pengolahan data tersebut diolah dengan menggunakan SPSS versi 20. Pengambilan keputusannya sendiri dilihat dari probabilitas Chi Squares, dimana jika probabilitas Chi Squares lebih rendah dari pada tingkat signifikansi ( $\alpha=5 \%$ ), maka dinyatakan signifikan, selain itu apabila $C h i$ Squares lebih besar dari tingkat signifikansi $(\alpha=5 \%)$, maka tidak signifikan (Widarjono, 147 : 2010).

Untuk interpretasi dilakukan lewat angka Odds ratio, dimana dalam SPSS versi 20 terdapat pada kolom Exp (B)(Widarjono: 142: 2010). Nilai sig. dari hasil pengolahan data menunjukkan nilai 0.016. Nilai tersebut lebih kecil dari nilai tabel $(0.016<0.05)$ yang berarti variabel Konsistensi memberikan pengaruh terhadap loyalitas nasabah BMT Berkah Mandiri Sejahtera dengan alasan bahwa perhitungan nisbah yang diterapkan pada BMT Berkah Mandiri Sejahtera cukup konsisten dengan kesepakatan pada awal akad. Kolom B menunjukkan koefisien dari variabel konsistensi, sehingga model yang dapat dibentuk dari hasil analisis ini adalah sebagai berikut:

$Y_{i}=\alpha+\beta X_{2}+\mu i$

$Y_{i}=0.541$ konsistensi

Pada tabel terdapat kolom Exp(B)dalam variabel konsistensi sebanyak 1.214 kali lebih tinggi pengaruhnya dibandingkan dengan yang tidak sesuai. Dengan demikian variabel konsistensi memberikan pengaruh yang signifikan.

Selanjutnya pada variabel konsistensi memperlihatkan nilai sig. Sebesar 0.013, nilai ini juga lebih kecil dari nilai 0,05
$(0.013<0.05)$ yang berarti variabel Proporsi memberikan pengaruh terhadap loyalitas nasabah BMT Berkah Mandiri Sejahtera dengan alasan bahwa perhitungan nisbah yang diterapkan pada BMT Berkah Mandiri Sejahtera cukup konsisten dengan kesepakatan pada awal akad. Pembagian proporsi untuk masingmasing pihak antara nasabah dengan BMT itu didasarkan atas seberapa besar dana yang didepositokan oleh nasabah kepada BMT, setelah itu dihitung bagian porsi pendapatan yang diperoleh antara nasabah dan BMT. Kolom B menunjukkan koefisien dari variabel konsistensi, sehingga model yang dapat dibentuk dari hasil analisis ini adalah sebagai berikut:

$Y_{i}=\alpha+\beta X_{2}+\mu i$

$Y_{i}=0.458$ konsistensi

Pada tabel terdapat kolom $\operatorname{Exp(B)}$ dalam variabel konsistensi sebanyak 1.381 kali lebih tinggi pengaruhnya dibandingkan dengan yang tidak sesuai porsinya. Dengan demikian variabel konsistensi memberikan pengaruh yang signifikan.

Berdasarkan hasil olah data maka terlihat nilai sig dengan nilai $0.010<0.05$ yang berarti variabel Transparansi memberikan pengaruh terhadap loyalitas nasabah BMT Berkah Mandiri Sejahtera. Variabel ini juga paling berpengaruh dibandingkan dengan variabel lainnya, dengan alasan karena pada setiap perhitungan nisbah bagi hasil pihak BMTmemberikan penjelasan dengan secara jelas dan detail atas perolehan nasabah.

Kolom B menunjukkan koefisien dari variabel konsistensi, sehingga model yang dapat dibentuk dari hasil analisis ini adalah sebagai berikut:

$\mathrm{Y}_{\mathrm{i}}=\alpha+\beta \mathrm{X}_{2}+\mu \mathrm{i}$

$Y_{\mathrm{i}}=0.458$ konsistensi

Pada tabel terdapat kolom Exp(B)dalam variabel konsistensi sebanyak 
1.455 kali lebih tinggi pengaruhnya transparansinya. Dengan demikian variabel konsistensi memberikan pengaruh yang signifikan.

\section{Analisis Chi Square}

Berdasarkan hasil perhitungan chi kuadrat, maka nilai chi kuadrat hitung 4,266 untuk variabel konsistensi, 4,266a, variabel proporsi 7.466a , variabel transparansi $18.133^{\mathrm{a}}(\mathrm{dk})=\mathrm{n}-1=2-1=1$.

Berdasarkan $\mathrm{dk}=1$ dengan taraf signifikan sebesar $5 \%$, maka diperoleh chi kuadrat tabel 3.481. Diketahui bahwa nilai chi kuadrat hitung lebih besar dari pada chi kuadrat tabel $\left(4,266^{\mathrm{a}}, 7.466^{\mathrm{a}}, 18.133^{\mathrm{a}}>\right.$ 3.481) dengan demikian Ho ditolak, dalam artian bahwa pertanyaan konsistensi, proporsi dan transparansi berpengaruh terhadap loyalitas nasabah BMT.

\section{KESIMPULAN DAN IMPLIKASI}

Berdasarkan penelitian yang telah dilakukan terhadap nasabah deposito mudharabah di BMT Berkah Mandiri Sejahtera, maka kesimpulan yang dapat dihasilkan adalah sebagai berikut, untuk mengetahui tingkat pengaruh nisbah bagi hasil deposito mudharabah terhadap loyalitas nasabah dalam penelitian ini variabel $\mathrm{x}$ (nisbah bagi hasil) dibagi menjadi tiga, diantaranya; konsistensi, proporsi dan transparansi.

Berdasarkan analisis data yang didapat bahwa variabel transparansi memiliki nilai sig. $0.010<0.05$, yang berarti variabel transparansi sangat berpengaruh terhadap loyalitas nasabah BMT Berkah Mandiri Sejahtera. Disamping itu, variabel transparansi memiliki nilai Odds Ratio lebih tinggi dibanding variabel lainnya, yaitu sebesar 1.455 .

\section{DAFTAR PUSTAKA}

Andi Sri Wahyuni. 2013. Penyesuaian Konsep Bagi Hasil Adat Syariah.

Antonio, M. Syafi'i. 2001. Bank Syariah Teori dan Praktek, Jakarta: Gema Insani Press dengan Tazkia Cendikia.

Barnes, G.James. 2002. Secret of Customer Relationship Manajement, Rahasia Manajemen Hubungan Pelanggan. Jakarta: Gramedia Pustaka Utama.

Cahyo, Gunawan Tri. 2008. Pengaruh Rasio Profitabilitas Perbankan Syariah Terhadap Penentuan Nisbah Bagi Hasil. UIN Syarif Hidayatullah.

http://www.spssindonesia.com/2015/01/ uji-chi-square-dengan-spsslengkap.html

Fauzia, Ika Yunia. Abdul Kadir Riyadi. 2014. Prinsip Dasar Ekonomi Islam Perspektif Maqashid Al-syari'ah. Jakarta: PT. Fajar Interpratama Mandiri.

Ghafur Anshori, abdul. 2009. Perbankan Syariah Indonesia. Yogyakarta: Gadjah Mada University Press.

Griffin, Jill. 2003. Customer Loyalti. Menumbuhkan dan Mempertahankan Kesetiaan Pelanggan, alih bahasa Dwi Kartini. Jakarta: Erlangga.

Gunawan Yasni, Muhammad. 2007. Ekonomi Sufistik. Bandung: PT. Mizan Pustaka.

Huda, Nurul. Heykal Mohamad. 2010. Lembaga Keuangan Islam. Jakarta: Kencana Prenada Media Group.

Hurriyati, Ratih. 2005. Bauran Pemasaran dan Loyalitas Konsumen. Penerbit: Alfabeta, Bandung.

Iska, Syukri. 2012. Sistem Perbankan Syariah di Indonesia. Yogyakarta: Fajar Media Press. 
Karim, Adiwarman. 2010. Analisis Fiqih \& Keuangan. Jakarta: PT. Raja Grafindo Persada.

Karim, Adiwarman. 2011. Analisis Fiqih \& Keuangan. Jakarta: PT. Raja Grafindo Persada.

Muhammad. 2012. Teknik Perhitungan Bagi Hasil dan Pricing di Bank Syariah, Yogyakarta: UII Press.

Muslich, Ahmad Wahyudi. 2010. Fiqih Muamalat. Jakarta: Amzah.

Muhammad Fatibut Timami dan Ady Soejoto. 2013. Pengaruh dan Manfaat Bagi Hasil Terhadap Jumlah Simpanan Deposito Mudharabah Bank Syariah Mandiri DI Indonesia.

Nurgiyantoro, Burhan., Gunawan., Marzuki. 2012 Statistik Terapan untuk Penelitian Ilmu-Ilmu Sosial. Yogyakarta: UGM Press.

Nurhayati, Sri. Wasilah. 2013. Akuntansi Syariah di Indonesia. Jakarta: Salemba, Empat.

Philip, Kotler., Hoon Ang, Swee., Meng Leong, Siew., \& Chin Tiong Tan. 2000. Manajemen Pemasaran Persfektif Asia. Terj. Fandy Tjiptono, Yogyakarta: Andi.

Purnama, Yuda. 2014. Pengaruh Aktivitas Media Twitter BRI Syariah Terhadap Kepuasan Nasabah BRI Syariah. Universitas Djuanda Bogor.

Riduwan, Rusyana, Adun, Enas. 2013. Cara Mudah Belajar SPSS Versi 17.0 dan Aplikasi Statistik Penelitian. Bandung: Alfabeta.

Ridwan, Muhammad. 2004. Manajemen Baitul Mal Wat Tamwil (BMT). Yogyakarta: UUI Press.

Rismawati dan Siti Ita Rosita, 2014. Pengaruh Sistem Bagi Hasil Deposito Mudharabah Terhadap Minat Nasabah Berinvestasi Pada Bank Syariah.
Siregar, Sofyan. 2013. Statistik Parametrik untuk Penelitian Kuantitatif. PT Bumi Aksara: Jakarta.

Slamet, Wiyono. Maulamin Taufan. 2013. Memahami Akuntansi Syariah Di Indonesia. Jakarta: Mitra Wacana Media.

Sugiyono, 2013. Metode Penelitian Kombinasi (Mixed Methods). Cetakan ke-3 Penerbit Alfabeta, Bandung.

Sujarweni, V. Wiratna. 2014. Metodologi Penelitian. Cetakan Pertama, Yogyakarta.

Sumiyanto, Ahmad. 2008. BMT Мenuju Koperasi Modern. Yogyakarta: ISES Publishing.

Sunyoto, Danang. 2013 Metode dan Instrumen Penelitian. Caps: Yogyakarta.

Wahyuni, Isni. 2008. Pengaruh Sistem Pelayanan dan Kepuasan Terhadap Loyalitas Nasabah. Universitas Islam Negeri Sunan Kalijaga.

Nurhayati, Sri. Wasilah. 2013. Akuntansi Syariah di Indonesia. Jakarta: Salemba,Empat.

Philip, Kotler., Hoon Ang, Swee., Meng Leong, Siew., \& Chin Tiong Tan. 2000. Manajemen Pemasaran Persfektif Asia. Terj. Fandy Tjiptono, Yogyakarta: Andi.

Purnama, Yuda. 2014. Pengaruh Aktivitas Media Twitter BRI Syariah Terhadap Kepuasan Nasabah BRI Syariah. Universitas Djuanda Bogor.

Riduwan., Rusyana., Adun., Enas. 2013. Cara Mudah Belajar SPSS Versi 17.0 dan Aplikasi Statistik Penelitian. Bandung: Alfabeta.

Ridwan, Muhammad. 2004. Manajemen Baitul Mal Wat Tamwil (BMT). Yogyakarta: UUI Press.

Rismawati dan Siti Ita Rosita, 2014. Pengaruh Sistem Bagi Hasil Deposito 
Mudharabah Terhadap Minat Nasabah Berinvestasi Pada Bank Syariah.

Siregar, Sofyan. 2013. Statistik Parametrik untuk Penelitian Kuantitatif. PT Bumi Aksara: Jakarta.

Slamet, Wiyono. Maulamin Taufan. 2013. Memahami Akuntansi Syariah Di Indonesia. Jakarta: Mitra Wacana Media.

Sugiyono, 2013. Metode Penelitian Kombinasi (Mixed Methods). Cetakan ke-3 Penerbit Alfabeta, Bandung.

Sujarweni, V. Wiratna. 2014.Metodologi Penelitian. Cetakan Pertama, Yogyakarta.

Sumiyanto, Ahmad. 2008. BMT Menuju Koperasi Modern. Yogyakarta: ISES Publishing.

Sunyoto, Danang. 2013 Metode dan Instrumen Penelitian. Caps: Yogyakarta. 